\title{
The role of litigation in tobacco control
}

Marlo Miura, JD, MA,(1) Richard A. Daynard, PhD, JD,(1) Jonathan M. Samet, MD, MS.(2)

\begin{abstract}
Miura M, Daynard RA, Samet JM.
The Role of Litigation in Tobacco Control. Salud Publica Mex 2006;48 suppl I:SI2I-SI36.
\end{abstract}

\begin{abstract}
There is now 50-years of experience in the United States litigating against the tobacco industry. As the base of evidence regarding health effects has evolved and new legal strategies have emerged, successive waves of litigation have occurred. The many failures by the first and second waves were followed by some notable successes in the third. Litigation by flight attendants and the states led to substantial settlements and some beneficial consequences for tobacco control. One of the most significant consequences of state litigation was access to the industry's documents, gained through the Minnesota settlement. These documents further empowered the tobacco control movement and strengthened the basis for legal action. The continuing litigation in the United States remains a threat to the industry, in spite of the mixed outcomes of recent cases.
\end{abstract}

Key words: Litigation; tobacco; control; industry; legal
Miura M, Daynard RA, Samet JM.

El papel del litigio en el control del tabaco. Salud Publica Mex 2006;48 supl I:SI21-SI36.

\section{Resumen}

Existe en los Estados Unidos una experiencia 50 años de litigios contra la industria del tabaco. La base de evidencia recopilada en relación con los efectos de la salud ha respaldado una nueva estrategia legal, lo que a su vez ha desencadenado sucesivas oleadas de conflicto. Los errores de la primera y segunda oleada fueron relevados por algunos éxitos notables en la tercera. Asimismo, los pleitos con asistentes de vuelos y con los estados condujeron al establecimiento substancial de algunos beneficios para controlar el consumo de tabaco. Uno de los resultados más significativos de litigio estatal ganado en el estado de Minnesota fue el acceso a los documentos de la industria. Estos documentos fomentaron el movimiento del control del tabaco y consolidaron la base para su demanda legal.Así, el continuo pleito en los Estados Unidos sigue siendo una amenaza para la industria tabacalera, a pesar de los resultados contradictorios de casos recientes.

Palabras clave: litigio; tabaco; control; industria; legal
I $\mathrm{n}$ the last decade, tobacco litigation has transformed tobacco control, providing another strategy in the tobacco control armentarium for limiting the tobacco industry's activities and providing redress to persons injured by use of tobacco products. One of the most powerful consequences of the recent litigation has been the forced release of the industry's internal docu- ments that are in depositories in Minneapolis, Minnesota and in Guildford, England and with the exception of the British American Tobacco documents, largely available in electronic data bases accessible on line. ${ }^{1,2}$ These recent successes, however, come at the end of nearly a half-century of litigation against the industry, following the identification of cigarette smoking as a

(I) Public Health Advocacy Institute. Boston, USA.

(2) The Johns Hopkins University Bloomberg School of Public Health, Department of Epidemiology, and the Institute for Global Tobacco Control. Baltimore, USA.

Accepted on: April 10,2006

Address reprint requests to: Jonathan M. Samet. The Johns Hopkins University Bloomberg School of Public Health, Department of Epidemiology and the Institute for Global Tobacco Control.6I5 N.Wolfe Street, Rm. W604I, Baltimore, Maryland 2I 205, USA.

Email: jsamet@jhsph.edu 
cause of lung cancer and other diseases in the 1950s. In fact, the potential for litigation and the related need for risk management have figured prominently in the tactics of the tobacco industry since the early 1950s.

This paper provides an overview of litigation as a strategy for tobacco control. It describes the experience in the United States, the most extensive of any developed country, and also key cases in other countries. The approaches that have been followed in these countries are particular to the laws of these countries and past litigation experience. While there may be some general lessons from the examples that we describe, the underlying principles and litigation strategies should be considered in other legal contexts with great care. Nonetheless, there is now substantial experience showing that litigation can be used successfully against the tobacco industry and to advance public health.

\section{The use of scientific evidence in tobacco litigation}

Scientific evidence has played a key role in litigation against the tobacco industry; the range of issues that has been addressed is broad, although particular cases may relate to a specific scientific matter (table I). The evidence causally linking active and passive smoking has proved fundamental, showing that smokers are injured by their use of tobacco and that smoking causes disease. Additional issues in litigation to date that have involved use of scientific evidence include the costs of diseases caused by smoking and of the smoking-related reduction of health in general, the impact of advertising, and the consequences of production characteristics, such as machinemeasured yield of tar and nicotine.

In both individual and class cases, causation of disease by cigarette smoking has been a foundation for the litigation; similarly, in the cases brought by the individual states against the tobacco industry, the fact that smoking causes disease has been the basis for estimating and requesting recovery of the costs to the states for participants in their Medicaid programs. With regard to tobac-

\section{Table I}

\section{SCIENTIFIC ISSUES IN TOBACCO LITIGATION}

\begin{tabular}{ll} 
- & Causation of disease by active smoking in specific individuals and groups \\
\hline - & Causation of disease by passive smoking in individuals and groups \\
\hline - & Risks of lower yield cigarettes \\
\hline & Addiction by cigarettes
\end{tabular}

co smoking, and cigarette smoking specifically, the evidence has been periodically subjected to systematic review by expert panels for the purpose of causal inference. The general approach for these reviews reflects that employed in the landmark 1964 report of the US Surgeon General, one of the first to conclude that smoking is a cause of lung cancer. ${ }^{3}$ That report set out an approach for evidence review and causal inference that is still in use. The report evaluated the entirety of the evidence in an objective and comprehensive fashion using pre-specified criteria for causal inference, often referred to as the Surgeon General's criteria or guidelines (table II). Remarkably, since the 1964 report, smoking has been causally linked to an increasingly lengthy list of disease and other adverse consequences. The 2004 report of the U.S. Surgeon General, for example, added cancers of the stomach and the cervix and acute myeloid leukemia to the smoking-caused malignancies ${ }^{4}$ (table III). Since the mid1980s, the evidence on passive smoking and health has been similarly reviewed with causal conclusions related to both children and adults (table IV).

In litigation to date, these causal conclusions have been used for two purposes: to infer that smoking damaged the health and caused disease in a group of smokers, e.g., all smokers in the state Medicaid system for Minnesota or that smoking caused disease in a specific individual. Inference about causation in particular groups defined for litigation purposes is a readily justified extension of a causal conclusion. In inferring that smoking causes disease, the implication is that smoking is a cause of disease generally; the causal conclusion does not exclude the possibility that risk may be different in subsets of the population based on the presence of other exposures, e.g., asbestos, or genetic factors. Repeatedly, in the state cases and in class action cases, e.g., Engle, the causal conclusions of the Surgeon Generals' reports and other expert reviews were presented as a basis for inferring that smoking caused disease in the group under consideration. Any rebuttal placed experts for the tobacco industry in the position of arguing against the Surgeon General, the World Health Organization, and other incontestable sources.

\section{Table II Causal criteria}

I. The consistency of the association

2. The strength of the association

3. The specificity of the association

4. The temporal relationship of the association

5. The coherence of the association

Source: Reference 3 


\section{Table III \\ Diseases CAUSED BY SMOKING, AS FIRST IDENTIFIED BY MAJOR HEALTH REPORTS}

\begin{tabular}{ll} 
Major disease category & \multicolumn{1}{c}{ Disease } \\
Cancer & Bladder \\
\hline & Cervical \\
\hline & Esophageal \\
\hline & Kidney \\
\hline & Laryngeal \\
\hline & Leukemia \\
\hline Lung & Oral \\
\hline Pancreatic \\
\hline Stomach \\
\hline Abdominal aortic aneurysm \\
\hline Atherosclerosis \\
\hline Cerebrovascular disease \\
\hline Coronary heart disease \\
\hline Chespiratory diseases & Phronic obstructive pulmonary disease (COPD) \\
\hline & Respiratory effects in utero \\
\hline Respiratory effects in childhood and adolescence \\
\hline Respiratory effects in adulthood \\
\hline Other respiratory effects
\end{tabular}

Reproductive outcomes Fetal death and stillbirths

Fertility

Low birth weight

Pregnancy complications

Other health effects Cataracts

Diminished health status/morbidity

Hip fractures

Peptic ulcer disease

The extension of the causal conclusions and underlying epidemiological evidence to specific individuals is inherent to litigation involving individual cases. In these cases, the proposition needing to be supported is that smoking caused disease in this particular individual to "a reasonable degree of medical certainty." The expert is asked to attest that the level of certainty meets the legal threshold of "more likely than not," sometimes interpreted as a probability of causation in the individual above $50 \%$. In using epidemiologic measures of association to estimate probability of causation, the parameter of attrib- utable risk in the exposed $\left(\mathrm{AR}_{\mathrm{E}}\right)$ is often used, either explicitly or implicitly. This measure is calculated as:

$$
\mathrm{AR}_{\mathrm{E}}=(\mathrm{RR}-1) / \mathrm{RR}
$$

where $\mathrm{RR}$ is the relative risk associated with exposure. The measure describes the additional risk in those exposed. For example, the relative risk for lung cancer in current smokers in the United States is presently about 20 , so that $\mathrm{AR}_{\mathrm{E}}$ for current smokers is $0.95(19 / 20)$. This estimate greatly exceeds the figure of $50 \%$ that has been proposed as a "bright line" for reaching a causal conclusion in an individual. However, for some diseases caused by smoking, the RR estimates are much lower and the resulting $\mathrm{AR}_{\mathrm{E}}$ estimates can be below $50 \%$. Nonetheless, smoking is certain to be contributing to the causation of individuals with such diseases but for any particular individual we lack tools to calculate a specific probability to a high degree of certainty and generally use the average probability of causation for persons with the smoking profile of the individual of concern as the best estimate.

In litigation to date in the United States, the epidemiologic evidence has been used in addressing issues other than causation, including the consequences of modifications made to cigarettes that have led to reduced yield of tar, nicotine, and carbon monoxide, as assessed with standard protocols that use smoking machines. The Miles (now known as the Price case) class action litigation in the State of Illinois was based in a claim of fraud around the beneficial health implications of labeling and marketing cigarettes with the "light" designation. Similarly, in the litigation brought by the U.S. Department of Justice against the tobacco industry, one of the main elements in the claim of racketeering and fraudulent and corrupt business practices was related to deceptive marketing of cigarettes with reduced yields, as assessed by a machine. The relevant epidemiological and other evidence has recently been reviewed by the U.S. National Research Council, ${ }^{13}$ the International Agency for Research on Cancer of the World Health Organization, ${ }^{11}$ the U.S. National Cancer Institute, ${ }^{14}$ and the U.S. Surgeon General; ${ }^{4}$ the reports are consistent in concluding that there is little evidence for reduced disease risk associated with using these products, in comparison with higher yield cigarettes.

In the litigation brought by the various states in the United States, it was necessary to estimate the health costs of smoking to the Medicaid systems of the states so that a scientifically justified claim could be made. The general approach to cost estimation involved application of the concept of attributable risk, but for estimation of the costs as the outcome of concern rather 
Table IV

AdVerse effects from exposure to SECONDHAND tobacco SMOKE

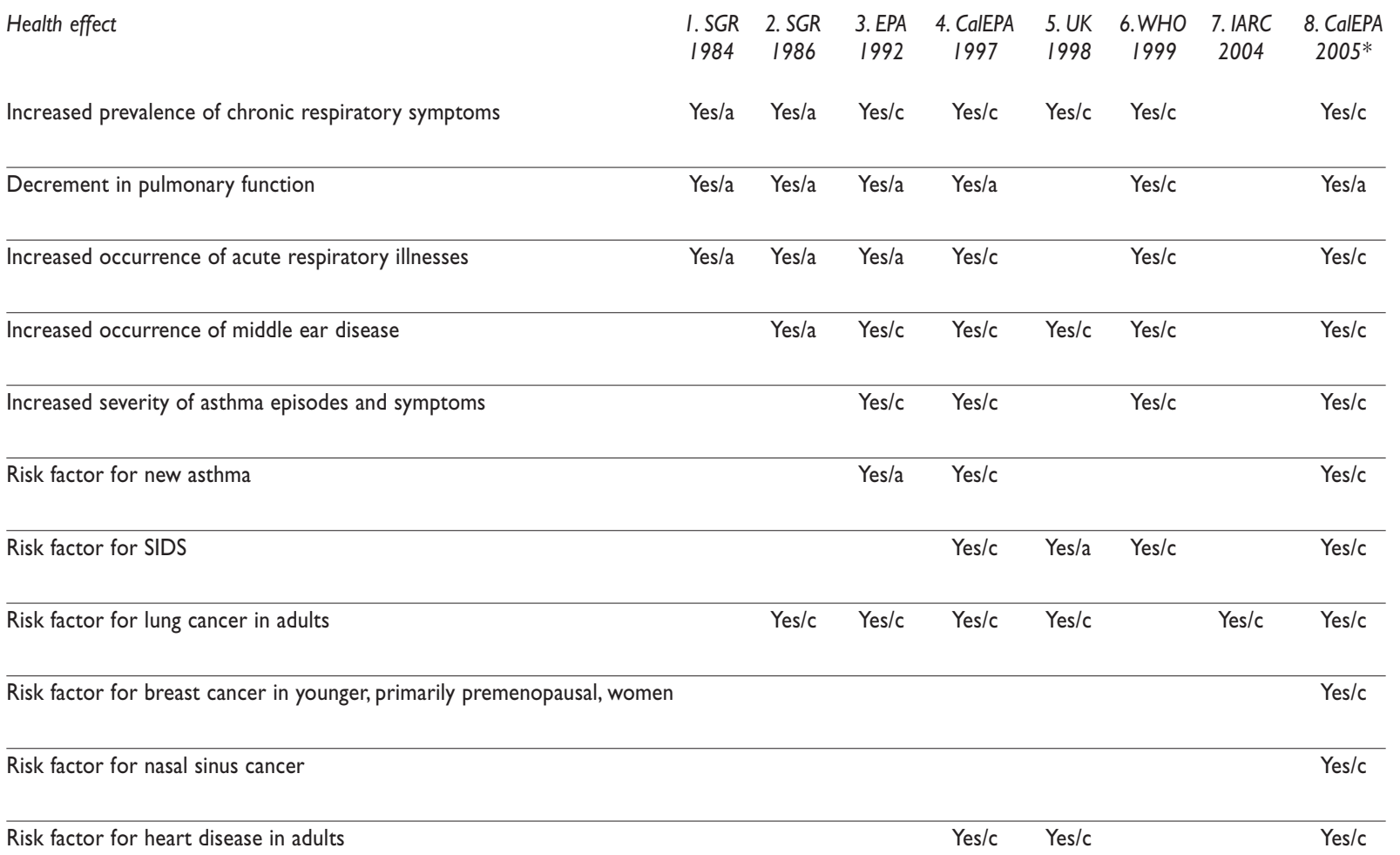

Yes/a = association

Yes/c = cause

*Only effects causally associated with ETS exposure are included.

I. Source: Reference 5

2. Source: Reference 6

3. Source: Reference 7

5. Source: Reference 9

6. Source: Reference 10

7. Source: Reference II

4. Source: Reference 8

8. Source: Reference 12

than the burden of illness. This approach is inherent, for example, in the estimation system and related programs developed by the U.S. Centers for Disease Control: Smoking Attributable Mortality, Morbidity, and Economic Costs (SAMMEC). ${ }^{4}$ A number of the states analyzed data from a national cohort study, the National Medical Expenditure Survey (NMES), which captures health events and costs for a cohort of Americans across a year. The data were analyzed with econometric approaches to develop attributable risk models for application to the Medicaid participants. The key measure estimated is the smoking attributable fraction, that is, the percentage of expenditures for particular diseases attributable to smoking.

More detailed information on the approaches used to estimate health costs has been published.
Zeger et al. ${ }^{15}$ describe the methodology used by the Minnesota plaintiff's team. The approach involved use of the NMES data to estimate the health costs associated with smoking, both for specific diseases caused by smoking and for those excess episodes of health care utilization that were a consequence of the diminished health of smokers in general. Actual billing records for individuals covered by the Medicaid program and by Blue Cross/Blue Shield of Minnesota (an insurer) were used and the likelihood of the individuals being smokers was imputed. The estimates of the smoking attributable fraction were then applied to calculate the smoking attributable expenditures.

Of necessity, the application of this type of model involves assumptions and the technical aspects of the estimation procedure are inevitably questioned by de- 
fense experts. Rubin, who has testified for the tobacco companies, details some of these concerns in an essay published in 2000. ${ }^{16}$

Other issues in tobacco litigation have involved health research evidence and have led to the engagement of scientists as experts. The impact of advertising and promotion, particularly on children has been one point of contention. Experts have been called on to opine on whether industry activities increased the number of youths starting and then continuing to smoke. The history of the tobacco industry and its activities in relation to the emergence of the evidence on diseases caused by smoking has also been addressed in the courtroom.

The process of litigation against the tobacco industry is inherently adversarial and those scientists who agree to serve as experts in cases against the industry should anticipate a potentially combative process on a playing field quite distinct from that in which scientific matters are typically debated. Elsewhere, one of the authors of this paper (JMS) has described his experience as an expert in the Minnesota litigation. ${ }^{17}$

\section{Review of US tobacco litigation}

\section{The first and second wave}

In 1952, Reader's Digest ran an article entitled "Cancer by the Carton" which described the emerging evidence linking cigarette smoking to lung cancer. ${ }^{18}$ The publication of the article in a magazine widely circulated throughout the United States initiated wider awareness in the general populace that smoking tobacco causes fatal health problems. This new knowledge started the first wave of tobacco litigation in 1954 when Ira C. Lowe, a Saint Louis factory worker, filed a products liability suit against the tobacco industry. The Plaintiff, Lowe, was a factory worker in Missouri whose right lung was removed due to cancer; the defendants in the case were four cigarette companies who produced the cigarette brands Lowe smoked and the store where he bought his cigarettes. Lowe sued for breach of warranty, stating that he had '"accepted the defendants' public assurances that their cigarettes were free from harmful substances. ${ }^{19}$ However, Lowe did not succeed and over the next four decades the tobacco industry never settled a case or paid any compensation to the plaintiffs.

Individual plaintiffs bringing suits under theories of negligence, deceit, and breach of warranty characterized the first wave of litigation against the tobacco industry. ${ }^{20}$ At issue in these cases was causation and the plaintiff's "freedom of choice" to smoke. The plaintiff's knowledge about the hazards of smoking was not an issue during the first wave, because the dangers of smok- ing were then not common knowledge at the time the plaintiff started and continued to smoke.

During the first wave of litigation, the tobacco industry's success was largely due to the plaintiffs' struggle to prove causation because of the lack of adequate medical evidence showing that cigarette smoking caused cancer and other diseases. During this time, the tobacco companies maintained a solid public façade that cigarettes were not harmful. The tobacco companies also uniformly devised a successful litigation strategy: never settle the case and exhaust the plaintiff with extensive procedural acrobatics.

The defendant tobacco companies, with their substantial resources, would take lengthy depositions and file a snowstorm of motions. Often, the defense would attempt to put the plaintiff on trial, investigating into every detail of the plaintiff's past. The typical first wave case consisted of an individual plaintiff and his or her attorney; the attorney usually had very limited resources and worked on a contingency fee, funding the costs of the litigation for a percentage of any awards. Eventually both the plaintiff and the plaintiff's attorney would be financially and emotionally bankrupted by the protracted litigation. Additionally, because the plaintiff could not afford the costs of starting a new trial, the plaintiff as a practical matter could not move for a mistrial based on the misconduct of the defendant's attorneys. ${ }^{21}$

In 1964, the first Surgeon General's Report reached the conclusion that smoking caused several diseases, including lung cancer in men. It stated that "[i]n view of the continuing and mounting evidence from many sources, it is the judgment of the Committee that cigarette smoking contributes substantially to mortality from certain specific diseases and to the overall death rate." ${ }^{\prime 3}$ The release of this report continued the growing public awareness that cigarette smoking causes disease, and it also presented the developing body of medical evidence that could be used in court to prove causation.

During the second wave, after the connection between smoking and disease had been established in the public's eye, the tobacco industry still attempted to shift the focus of the cases onto the plaintiff rather than the company or the product. In 1965 the Federal Cigarette Labeling and Advertising Act was established to require all cigarette packages and advertising to contain a warning label. The tobacco industry used this act to strengthen its defensive shield -arguing that because of the labels the plaintiff knowingly and voluntarily "assumed the risk of" or negligently "contributed to causing" the harms of smoking. ${ }^{20}$ Assumption of risk and contributory negligence are harsh legal defenses that act as a complete bar to recovery for the plaintiff. 
However, plaintiffs' attorneys added the new theories of failure to warn and strict liability to their suits. ${ }^{20}$ Strict liability helped shift the focus from the parties to the product. ${ }^{22}$ In addition, the beginning of the second wave came at a time when the courts began to apply the theory of comparative fault to strict product liability. This dampened the defense's strategy of focusing on the plaintiff's actions, because it allowed in certain jurisdictions for fault to be apportioned between the plaintiff-smoker and the defendant-tobacco company. Therefore, despite the defense's tactics, such as focusing on the plaintiff's conduct and his or her alleged freedom of choice in smoking, the plaintiff could have a "partial victory" with an award based on the defendant's percentage of fault. ${ }^{23}$

The second wave began in the 1980's because of the change in public attitude that spawned the United State's anti-smoking movement. Although freedom of choice and causation were still central issues in the cases, these issues were framed in a different environment -one where consumer protection groups were developing and toxic torts were in the spotlight. ${ }^{14}$ Plaintiffs and their attorneys also began to receive more direct support. As more cases against the tobacco companies were filed, plaintiffs' attorneys and the health movements began to organize and pool resources. "Thus, in the two most prominent second wave cases, Cipollone and Horton v. American Tobacco Co., plaintiffs' lawyers sought to join ranks with colleagues in order to respond effectively to the anticipated blizzard of pretrial motions, depositions, and other procedural moves." ${ }^{21}$ Today, technology has allowed attorneys and organizations to easily share useful litigation strategy and materials with colleagues around the world.

For instance, the legal team for the plaintiff in Boeken v. Philip Morris developed a complete collection of materials related to the trial entitled "Trial-in-a-Box." Materials include internal tobacco company research documents from the first wave era identifying the carcinogenic components in cigarettes and frankly discussing the addictive nature of nicotine. Motions, trial transcripts, and submitted evidence, among other things, are also provided. This resource is hosted for free by the Tobacco Products Liability Project in an effort to disseminate evidence to the legal community that has proved successful in previous trials. ${ }^{24}$

Cipollone v. Liggett Group, A Key Second Wave Case: In Cipollone v. Liggett Group, Rose Cipollone and her husband, Antonio Cipollone, brought a products liability suit against several tobacco companies after Rose Cipollone was diagnosed with lung cancer. The suit brought claims of strict liability, negligence, intentional tort and breach of warranty. Rose Cipollone began smoking in 1942 at the age of 17 and smoked two packs a day until she quit smoking in 1983; she passed away in 1984. This case was bitterly fought on both sides with the tobacco companies' practiced flurry of motions and appeals.

Cipollone was the first case in which a jury was allowed to view the tobacco companies' internal documents that detailed the industry's concerted effort to mislead the public about the dangers of smoking. ${ }^{24}$ After a fourmonth trial, the jury found that the tobacco companies had some comparative fault for breaching its express warranty that the product was safe for the period prior to the 1965 Federal Cigarette Labeling and Advertising Act (FCLAA). Therefore the jury awarded $\$ 400000.00$ in damages to Antonio Cipollone. This was the first financial award rendered against a tobacco company in a products liability case.

The defendants appealed the ruling up to the United States Supreme Court. In its 1992 opinion, the Supreme Court held that the FCLAA preempted any claims that the companies had to improve their warnings in advertisements and on the packaging above the minimal requirements under the FCLAA, as amended. However the Supreme Court made a point of clarifying that the FCLAA did not bar plaintiffs from bringing claims of express warranty, misrepresentation, conspiracy, or intentional fraud. ${ }^{25}$ Therefore plaintiffs could still bring suits based the tobacco industry's failure to disclose the dangers of smoking through means other than warning labels. ${ }^{26}$ The U.S. Supreme Court remanded the case on the issue of fraud. At this point, exhausted, the only surviving Cipollone family member and his attorneys decided to not pursue the remanded case.

\section{The third wave}

The Cippolone case and the evidence produced during the course of the trial provided the impetus for the third wave of tobacco litigation. Specifically, the Food and Drug Administration (FDA) began to review documents regarding the addictive nature of nicotine and whether the cigarette companies deliberately manipulated nicotine levels in cigarettes. For instance, those in the public became aware of this investigation on February 25, 1994, through a letter FDA Commissioner David Kessler sent to the Coalition on Smoking and Health. In that letter, Kessler indicated that if nicotine were addictive and the cigarette companies controlled nicotine levels in their products, then the cigarette industry would fall under the regulatory purview of the FDA. ${ }^{20}$

The media also began to report on this topic. Most notably, on February 28, 1994, a news program on net- 
work television broadcast a report that the cigarette industry manipulated nicotine levels to addict smokers to cigarettes. ${ }^{20}$ Although the television network later ran a retraction -when faced by the threat of protracted litigation by the industry- the information was now open for general discussion.

Based on these events and the media attention, they created, a series of televised hearings on the tobacco industry's practices of nicotine manipulation took place. During the course of the hearings, testimony was heard on the issue and the tobacco companies were required to produce even more heretofore secret internal documents. The FDA released its finding that nicotine is an addictive, psychoactive drug and characterized cigarettes and smokeless tobacco produces as instruments used to deliver that drug. ${ }^{20}$ During the third wave, it became apparent that the cigarette industry secretly researched the effects of nicotine and other cigarette components, while publicly maintaining that they did not believe that cigarettes were addictive.

Changes in public sentiment regarding the plaintiffs also weakened the tobacco industry's "try the victim" strategy. During the first and second waves, the cigarette industry's defense effectively displaced fault to the plaintiff, focusing on the "freedom of choice" to smoke. Once nicotine's addictive effects, and the tobacco industry's attempt to modulate those effects, became public knowledge, that valuable strategy for the industry was substantially eviscerated.

In 1996, " $[t]$ he tide just went out on the companies," according to one lawyer." ${ }^{21}$ Liggett and Myers became the first cigarette company to ever settle in litigation with the settlement of the Castano class action suit and five state-brought suits. In addition to monetary damages and improving warning labels on their packaging, ${ }^{27}$ Liggett and Myers agreed in their settlements to produce even more evidence against the tobacco companies. ${ }^{27}$ The new information provided -along with emerging insider testimony- provided further valuable evidence on the internal practices of the tobacco companies.

The third wave began an era of victorious plaintiff suits. In the Boeken case, the plaintiff's attorneys successfully introduced compelling internal documents and expert witness testimony. The outraged jury in the Los Angeles County Superior Court case originally awarded the plaintiff, who contracted lung cancer after years of smoking cigarettes, \$5.54 million in compensatory damages and punitive damages in the amount of $\$ 3$ billion. ${ }^{28}$ The judge for the case subsequently refused to reverse the verdict or declare a mistrial, but did reduce the punitive damage amount to $\$ 100$ million..$^{29}$ An appeals court further reduced the punitive damages to $\$ 50$ million. The defendant, Philip Morris, appealed the case all the way to the United States Supreme Court. In the most recent development, on March 20, 2006, the United States Supreme Court declined to review the case, decisively cutting off the defendant's last avenue of appeal. This will be the largest award to be recovered by a single plaintiff: amounting to compensatory damages of $\$ 5.54$ million, punitive damages of $\$ 50$ million, and interest of over $\$ 26$ million. ${ }^{30}$

Another currently active single-plaintiff case in is Williams v. Philip Morris. In Williams, Mayola Williams sued Philip Morris after her husband died of lung cancer. The jury awarded the plaintiff $\$ 821,485.80$ in compensatory damages and $\$ 79.5$ million in punitive damages. The trial judge reduced the compensatory amount to $\$ 500,000.00$ and the punitive amount to $\$ 32$ million. The Oregon Court of Appeals reinstated the $\$ 79.5$ million award for punitive damages. The judgment amount was further appealed to the United States Supreme Court which remanded the case back to the Oregon Court of Appeals for reconsideration of the punitive damage award in light of the United State Supreme Court's recent decision in State Farm Insurance Co. v. Campbell. The Oregon Court of Appeals upheld its decision to restore the jury's punitive damage amount under the guidelines set by the United States Supreme Court, and the Oregon Supreme Court agreed to review this decision. In most recent news, on February 2, 2006, the Oregon Supreme Court found that Philip Morris's conduct was sufficiently outrageous and egregious to support the appeals court's second reinstatement of the $\$ 79.5$ million punitive damage award. ${ }^{31}$ For a detailed analysis of tobacco-related punitive damage awards in the United States, published shortly before the Oregon Supreme Court's decision, see Punishing Tobacco Industry Misconduct: The Case for Exceeding a Single Digit Ratio between Punitive and Compensatory Damages. ${ }^{32}$

New plaintiffs, new theories: During the third wave, new types of plaintiffs emerged. Non-smokers exposed to secondhand smoke, also referred to as Environmental Tobacco Smoke (ETS), began to bring suits against not only the tobacco companies but also other entities who allowed them to be exposed to ETS. States filed suits seeking recovery for medical costs caused by tobaccorelated disease. State plaintiffs had greater resources than the individual private citizen plaintiffs. These new plaintiffs were viewed as "blameless," since they suffered harm from a product they did not even use. In addition, state plaintiffs had greater resources than the individual private citizen plaintiffs. Plaintiffs' attorneys also began to pool their resources to instigate class ac- 
tion suits. For instance, the plaintiffs in the Castano $v$. American Tobacco case were represented by over 60 law firms which funded a $\$ 6$ million/year budget. ${ }^{14}$ One of the plaintiffs' attorneys stated: "We have enough talent and numbers to go toe-to-toe with the tobacco companies for the first time... . They simply cannot out-spend us, and that is important because the history of tobacco litigation is that companies have overwhelmed the plaintiffs." ${ }^{21}$ In addition, while the defendants' strategies were being undermined by the changing face of the plaintiff, plaintiffs' attorneys began to develop more sophisticated strategies. For example, case management orders were obtained in order to combat the tobacco companies' reprehensible discovery tactics. ${ }^{20}$

The information released to the public during the first and second waves brought new types of tobacco litigation during the third wave. Personal injury lawsuits continued, but the plaintiffs' attorneys had better evidence and could develop more complex cases. Lawsuits based on the development of "safer" cigarettes, addiction, ETS, and the marketing of "light" cigarettes became more common.

Cigarette fire cases are a type of product liability suit. Plaintiffs in these suits suffer physical, economic, and/or emotional damage as a result of fires caused by cigarettes. These are often blameless victims -children and non-smokers- who get caught in the blaze. In 1992, a young child under two years old was badly burned in a car fire allegedly caused by her mother's cigarette igniting the car's upholstery. The mother was in her grandparent's house delivering dinner at the time. Over $77 \%$ of the child's body was burned resulting in amputation, hearing loss, and impeded speech capabilities. The suit claimed that the cigarette was defectively designed, because it was deliberately designed to burn to the filter. Manufacturers design cigarettes in this way to boost sales -users find it convenient not to have to relight the cigarette, and the product is used more quickly. In 2003, after almost nine years in court, Philip Morris paid \$2 million to settle the cigarette fire lawsuit. This was the company's first settlement after decades of its policy to never settle. The Los Angeles Times broke the story -which would have otherwise been concealed because of the confidentiality clause in the settlement. ${ }^{33}$ One whistleblower for the tobacco industry thinks that cigarette fire cases will start another wave of litigation: "Now that the technology for fire-safe cigarettes exists, people are suing when cigarettes start fires." ${ }^{34}$ Before this recent settlement, approximately 15 cigarette fire cases had been dismissed in the United States before even going to trial. ${ }^{33}$

Addiction cases became more sophisticated. Plaintiffs sought damages for addiction based on their in- ability to quit separately from or in addition to the corresponding health consequences. A growing body of scientific evidence established that nicotine is addictive. Internal company documents and insider testimony from whistleblowers helped establish that tobacco companies knew nicotine was addictive, actively manipulated and monitored nicotine levels in their products to exploit addiction, secretly conducted related scientific experiments, and yet as a united industry continued to deny that tobacco products were addictive in public statements and marketing. Addiction claims against tobacco companies can be based on differing theories of liability including: negligence; strict liability; fraud; misrepresentation; breach of warranties; infliction of emotional distress; state consumer protection statute violations; conspiracy; antitrust violations; unjust enrichment; negligent performance of a voluntary undertaking; civil RICO violations; and criminal charges. ${ }^{20}$

Environmental tobacco smoke: The third wave cases also include ETS class action suits. The new plaintiffs -who either never smoked or infrequently smoked-alleged that exposure to ETS caused or substantially contributed to the development of smoking-related diseases. Attorneys often organized such plaintiffs into a class to file the suit. Class actions are subject to special procedural rules, and some class actions can bind a class even if each individual is not specifically named or identified. One of the more well-known ETS class actions is the Broin v. Philip Morris class action filed in Florida in 1991. The class consisted of flight attendants who suffered from smoking-related diseases or disorders from exposure to ETS while working in airplanes.

The Broin case went to trial, but the parties entered into a settlement agreement before a verdict was rendered. The named tobacco companies agreed to pay $\$ 300$ million to establish a scientific research foundation (the Flight Attendants Medical Research Institute) dedicated to the early detection and cure of smokingrelated diseases. The tobacco companies agreed to support federal legislation to prohibit smoking on international flights. Individuals in the class were given one year to file separate suits for compensatory damages; the settlement also shifted the burden of proof to the defendants for certain types of cases and made other provisions regarding the personal suits. However the settlement barred any exemplary or punitive damage award in those suits. The tobacco companies also agreed to pay attorneys' fees and costs for the plaintiff class (the settlement contemplated that $\$ 46$ million in fees and $\$ 3$ million in costs would be submitted for court approval; defendants agreed in the settlement not to object to the fee request). ${ }^{35}$ 
French v. Philip Morris, also filed in Florida, was one of the hundreds of individual plaintiff suits filed by flight attendants based on the Broin Settlement Agreement. The plaintiff claimed that she suffered chronic sinusitis from exposure to secondhand smoke while working in airplane cabins. In 2002, a jury awarded the plaintiff $\$ 5.5$ million in compensatory damages. The trial judge reduced the judgment to $\$ 500,000$. Defendants appealed the verdict. However the appeals court upheld the veredict, and the Florida Supreme Court declined review.

Other ETS cases involve plaintiffs seeking to ban public exposure to ETS and plaintiffs seeking compensation from their employers rather than the tobacco companies for damages suffered from exposure to workplace ETS. In 1983 a governmental employee filed a lawsuit against the Commonwealth of Massachusetts seeking to ban smoking in the government's workplaces in order to have a safer work environment. The state agreed to settle the case and banned smoking in its workplaces. ${ }^{36}$ Similar suits seeking to promote a smoke-free workplace have been filed in the United States under the Americans with Disabilities Act, the Rehabilitation Act and other state and federal regulations. Other suits involve employees suing their employers or the insurance companies based on workplace ETS exposure. Such lawsuits create strong incentives for employers and insurance companies to ban smoking in the workplace.

"Light" cigarettes: Many smokers smoke "light' and "low $\operatorname{tar}^{\prime \prime}$ cigarettes under the mistaken assumption that such cigarettes are less harmful than regular cigarettes. However, internal industry documents and independent studies by organizations such as the National Cancer Institute ${ }^{14}$ show that these "light" and "low tar" cigarettes are just as dangerous as regular cigarettes. Studies show that smokers alter their smoking habits by disabling the mechanism in the cigarette filter which dilutes the smoke and by compensating through deeper inhalation or increased smoking. Internal industry documents reveal that cigarette manufacturers were aware of these compensatory phenomena but intentionally deceived both the public and governmental regulatory agencies, such as the Federal Trade Commission. In marketing these products, the cigarette companies targeted smokers who felt anxious about their health but were too addicted to stop smoking. The cigarette companies also targeted smokers worried about their health who could potentially stop smoking, offering the "healthier" brands as an alternative to quitting.

Individual and class actions suits against the tobacco companies for fraud, negligence and other violations ensued. In 2002, an Oregon jury determined that Philip Morris lied to the public in marketing its "light" cigarettes and awarded the plaintiff, Marlene Schwartz, \$150 million in damages. The award was later reduced to $\$ 100$ million. In 2005, the Illinois Supreme Court overturned the trial court's award of $\$ 10.1$ billion dollars in the Price class action case. The Price case had been formerly known as the Miles case. The class in Price requested reimbursement for the economic harm they incurred in buying the misleading Marlboro Lights and Cambridge Lights brands. The trial court found that the tobacco company fraudulently misled consumers about the hazards of smoking "light" cigarettes and awarded compensatory and punitive damages. The trial court also approved of the plaintiffs' attorneys fees of $\$ 1775$ billion. In reversing the trial court's decision, the Illinois Supreme Court reasoned that the Federal Trade Commission had in a consent order "'specifically authorized" the cigarette company to use "light" and "low tar" designations. Therefore the Illinois Supreme Court found that the authorization triggered exemption from liability for the cigarette company pursuant to a section in the state's Consumer Fraud and Deceptive Practices Act. The Illinois Supreme Court remanded the case back to the trial court with instructions to dismiss the case. ${ }^{37}$

State settlement agreements: The third wave marked a shift in tobacco litigation from the private to the public sector. As litigation began to be viewed as an effective public health tool, state government entities began to file consumer protection suits against the tobacco companies. These suits claimed that the tobacco companies practiced unfair or deceptive trade strategies and sought to stop such behavior through litigation. The states also sought recovery for the health care costs of treating illness and disease caused by smoking.

In 1994, Mississippi became the first state to sue the tobacco companies to recoup its health costs in The State of Mississippi v. American Tobacco. In 1997, a settlement was reached between Mississippi and the tobacco companies. Less than a year later three other settlements with Florida, Texas, and Minnesota, respectively, followed. These four settlements resulted in the tobacco industry agreeing to pay a total of $\$ 35.3$ billion over a 25-year period. Other provisions which some of the states secured involved continued annual payments after the 25-year period; monetary reimbursement to certain health insurance companies; the establishment of public health and tobacco control programs; tobacco advertising restrictions; and "most favored nation" clauses which allowed the respective settlement to automatically incorporate any subsequent, more favorable terms in any subsequent settlement with another state. ${ }^{38}$ 
Following these four settlements, the major tobacco companies sought to enter into a comprehensive settlement agreement with the states which had instituted suits against them. In 1998 -after protracted negotiations and a failed deal which would have required congressional approval- the remaining 46 states and 5 territories along with the four largest tobacco companies signed the Master Settlement Agreement (MSA). The MSA may be viewed on the National Association of Attorneys General website. ${ }^{39}$ The companies which participated in the MSA agreed to pay over $\$ 200$ billion over a 25-year period. Other provisions include restrictions on: outdoor advertising; distribution of promotional merchandizing; sponsorship of public events; targeting underage smoking; and political lobbying.

Two of the most notable consequences of the Minnesota settlement were the agreement to "release internal indexes to millions of previously secret industry documents, providing a road map to make it much easier for attorneys and researchers to find relevant information" and for the tobacco industry to pay for ten years to maintain a depository for the documents in both Minnesota and Great Britain. ${ }^{38}$ These provisions in the Minnesota settlement agreement provided the world with a valuable database and the means of navigating that information. The MSA further improved public access to the tobacco industry's documents by requiring the companies to fund, and continually update for ten years, a searchable website containing all the documents produced in tobacco and health-related lawsuits. Two resources for tobacco industry documents are the Tobacco Documents Online ${ }^{1}$ and the Legacy Tobacco Documents Library. ${ }^{2}$ For instance, The Tobacco Atlas lists that the Legacy website in 2002 had between 1,000 and 4,999 documents related to Mexico. ${ }^{40}$ The legend in The Tobacco Atlas indicates that " $[t]$ he higher the figure, the more important the country is to the industry[,]" and Mexico falls into the second-highest category. ${ }^{40} \mathrm{~A}$ general search for "Mexico" on the same website yielded 5,328 results on $03 / 27 / 06$; this search lacks specificity and would include, for example, terms such as "New Mexico." The documents available on those sites include confidential memos, private letters, scientific research reports, public relations and advertising strategy reports, court filings and transcripts, and litigation analysis. Thus, the course of litigation in the United States created a vast, searchable resource consisting of millions of internal tobacco industry and trial documents.

\section{The Department of Justice Case}

Less than a year after the state lawsuit settlements, the federal government also took aim at the tobacco com- panies. Like the state suits, the federal government sought through judicial action to stop the tobacco industry's concerted efforts to deceive the public about the dangers of smoking. In September 1999, the United States Department of Justice (DOJ) sued the tobacco industry under the Racketeer-Influenced and Corrupt Organizations Act (RICO). ${ }^{41}$ In addition, under different acts the DOJ sought reimbursement for the costs to the federal government of treating smoking-caused illnesses. While the reimbursement portion of the case was later dismissed, the case continued with the RICO charges. Under RICO, it is illegal for a person or entity "to conduct or participate, directly or indirectly, in the conduct of such enterprise's affairs through a pattern of racketeering activity or collection of unlawful debt." ${ }^{\prime 2}$ It is also illegal to conspire to conduct those activities. ${ }^{42}$ Racketeering activities include the mail and wire fraud charges alleged in this suit. ${ }^{41}$ The Complaint submits in chart form the numerous, specific violations the DOJ would seek to prove each defendant committed. ${ }^{43}$ RICO allows the DOJ to bring a civil suit for equitable relief in this instance to stop the industry's longstanding practice of profiting through deception. In various pretrial rulings, certain portions of the case and requested remedies were set aside on various legal grounds.

The suit charged the major tobacco companies and its two trade organizations of conspiring to actively defraud the public about tobacco's addictive nature and adverse health effects in addition to the industry's collective practices such as manipulating tobacco levels, misleading the public about "light" or "low tar" cigarettes, and targeting children. ${ }^{44}$ The trial commenced on September 21, 2004, and concluded on June 9, 2005. As of the publication of this article, a ruling is still pending. The DOJ's website provides a tobacco litigation page outlining the history of the suit and providing links to relevant court filings, testimony transcripts, and orders. ${ }^{45}$

Like the earlier state cases, the DOJ suit seeks remedial measures to help counter the massive damage caused by the tobacco industry's decades of deception. Some of these measures include: the allocation of $\$ 10$ billion dollars over five years to fund a stop-smoking program; the allocation of $\$ 4$ billion over 10 years for educational and anti-smoking marketing programs; the allocation of more money if target rate reductions set for youth smoking are not met by a certain date; further disclosure of internal documents such as hearing-related documents, marketing data, and health information; issuance of "corrective statements" by the companies; changes in business practices and company structure; and limits on future advertising and packaging. ${ }^{44}$

Remedies such as document disclosure would force the tobacco companies named in the DOJ suit to provide 
information to the public in a searchable format. This is important because similar arrangements under the Minnesota and the Master Settlement Agreement expire shortly: the terms for the physical depositories provided under the Minnesota Settlement Agreement in May, 2008, and the terms for the internet-based depositories under the MSA in June, 2010. ${ }^{44}$ The DOJ also wants the court to order the tobacco companies to provide detailed indices of all privileged or confidential documents not produced in trials. This would provide a more complete picture of all disclosed and "disclosed as being withheld" documents of a particular company. ${ }^{44}$

\section{Litigation in other countries}

\section{Framework Convention on Tobacco Control (FCTC)}

The World Health Organization responded "to the globalization of the tobacco epidemic" with the Framework Convention on Tobacco Control (FCTC). ${ }^{46}$ The FCTC "created general principles of cognitive and normative consensus for international public health, challenging the globalization of smoking through the globalization of tobacco control. ${ }^{\prime \prime 7}$ In order to obtain the necessary consensus, the governing body of the WHO decided to implement its first global health measure under a framework convention rather than as a treaty. Countries signing a framework convention "incur minimal obligations by doing so; states become bound by more specific commitments embodied in subsequently negotiated protocols only if they make a separate decision to do so." 48 The FCTC was unanimously adopted on May 21, 2003 during the 56th World Health Assembly, and it entered into force on February 27, 2005. As of April 4, 2006168 state parties have signed the FCTC, ${ }^{49}$ making it the most widely embraced treaty in UN history." ${ }^{150}$ Mexico signed the treaty on August 12, 2003, and ratified it on May 28, 2004. ${ }^{48}$

The FCTC seeks effective tobacco control through reducing both supply and demand for tobacco. Supply-reduction provisions in the FCTC focus on both "[p]rice and tax measures to reduce the demand for tobacco" and "[n]on-price measures to reduce the demand for tobacco[.]", ${ }^{46}$ articles 6 and 7. Specific provision were set up regarding: ETS protection; regulating product content; regulating product disclosure; regulating marketing; raising public awareness; "packaging and labeling"; and setting up programs to help addicted smokers to quit, ${ }^{46}$ articles 8-14. Demand-reduction provisions in the FCTC focus on: "illicit trade"; "sales to and by minors"; and a "provision of support for economically viable alternative activities", ${ }^{46}$ articles 15-17. The FCTC also contains a liability provision that states that the signatories shall consider changing or upholding their laws to "deal with civil and criminal liability" more effectively "for the purpose of tobacco control" ${ }^{46}$ article 19. It also states that that the signatories shall help each other in such litigation, ${ }^{46}$ article 19. Some health advocates have criticized the FCTC on the policy level for "discouraging consumption without encouraging cessation" of tobacco use. ${ }^{47}$ Others worry about the implementation, because many measures are only discretionary and there is no effective system in place. ${ }^{48}$ However, the FCTC remains an important step in setting global guidelines and opening an international dialogue regarding tobacco control.

\section{International litigation}

While the FCTC establishes global guidelines and opens transnational communication, litigation remains an important strategy in tobacco control. Tobacco is still big business, and the tobacco companies have developed sophisticated global strategies to maintain and grow the industry. Litigation can be a useful tool in nations attempting to use all available strategies to curb this costly epidemic.

Tobacco products are still being sold because tobacco remains a profitable business. The major tobacco companies are often part of large conglomerations and/ or multinational corporations. For instance, Altria Group, Inc. (Altria) is the parent company of Philip Morris USA Inc. (Philip Morris USA), Philip Morris International Inc. (PMI), Kraft Foods Inc. (as a majority stakeholder), Philip Morris Capital Corporation, and other interests. ${ }^{51}$ Altria's corporate headquarter is in New York. Philip Morris USA's headquarter is in Virginia. PMI's headquarter is in Lausanne, Switzerland. Altria disclosed in its 2005 Annual Report that net domestic tobacco revenues totaled over $\$ 18.1$ billion in 2005 -up $\$ 623$ million from the previous year. ${ }^{51}$ International tobacco net revenues totaled almost $\$ 45.3$ billion in 2005 up over $\$ 5.75$ billion from the previous year. ${ }^{51}$ Therefore, net tobacco revenues for Philip Morris USA and PMI totaled over $\$ 63.4$ billion. Philip Morris USA spent \$258 million to defend product liability suits in 2005. ${ }^{51}$

Ownership of multinational companies is concentrated in a small number of countries. As a result, tobacco profits from around the world end up in those same few countries while draining the wealth of the other countries through both tobacco sales and the damages caused by tobacco use. ${ }^{52}$ A director of a major tobacco company earns in one day the amount that a Brazilian tobacco farmer earns in six years. ${ }^{53}$

Countries lose productivity when people contract tobacco-caused diseases and become too ill to work or 
prematurely die. At the same time, countries must pay large health care costs to treat tobacco-caused illness. ${ }^{53}$ The same holds true on the personal level. Individuals and families bear higher medical costs while often losing wages when the person falls ill from tobacco exposure. In addition, "money spend on tobacco can have a very high opportunity cost. For the poor, money spent on tobacco is money not spend on basic necessities...". 53 In 1998, the poorest 20 percent of the Mexican population spent almost 11 percent of their earnings on tobacco products. ${ }^{53}$ "Research has shown... that over 10.5 million people in Bangladesh who are currently malnourished could have an adequate diet if money spent on tobacco were spent on food instead, saving the lives of 350 children under age five each day." 53

Litigation can help to return money to the many nations suffering health and economic losses due to tobacco use. ${ }^{52}$ Money recovered from the tobacco industry can fund remedial measures to defray medical costs spent by the country and to set up tobacco control programs. As an added benefit, reparations drive up the cost of tobacco products, thereby decreasing overall consumption. ${ }^{52}$

Litigation in each country promotes the discovery of industry materials particular to that country; it also personalizes the issue in that country. ${ }^{52}$ Correspondingly, local media attention increases public awareness. "Italian, Israeli and American litigation proved that the degree of coverage by the media of this [tobacco] litigation was far higher than in respect of any health information available." ${ }^{52}$

While "tobacco litigation is still relatively rare outside the USA", 54 the numbers of cases are growing. The Tobacco Atlas indicates that, as of 2002, there were no lawsuits filed in Mexico against the tobacco industry. ${ }^{40}$ Altria disclosed that as of December 31, 2005, there were approximately 268 active tobacco lawsuits against its subsidiaries in the United States. Altria did not include 2,650 cases brought by flight attendants for ETS exposure and counted as one a West Virginia case in which 928 people aggregated their claims into one case. ${ }^{51}$ It further disclosed that about "132 individual smoking and health cases" were currently pending outside of the United States ${ }^{51}$ reflecting a steady increase in individual plaintiff cases outside the United States, progressively up from 99 cases in 2003 and 121 cases in $2004 .{ }^{51}$ Altria chose not to include certain cases in Italy and Finland in this calculation. Altria also indicated there were "three smoking and health putative class actions pending outside the United States" in contrast with three case in 2004 and six cases in 2003. ${ }^{11}$ "Four health care cost recovery actions" in addition to "two Lights/Ultra Lights class actions" are still active. ${ }^{51}$
With tobacco consumption declining in some countries, the tobacco companies need expanding markets in other countries. For instance, the Altria 2005 Annual Report explains that between 2003 and 2004, "[i]n Latin America, [cigarette retail] volume decreased, driven mainly by declines in Argentina, partially offset by an increase in Mexico. ${ }^{\prime \prime 1}$ Consequently, the companies are concerned that the development of tobacco litigation in United States and the resulting changes in public awareness and attitudes towards the industry not be repeated in other countries. A 1998 British American Tobacco report states: ${ }^{55}$

We are seeing an immediate effect of the changing US environment in a number of countries closely aligned in some aspects of the US culture. An increase in litigation around the world and providing a framework for further regulatory controls are the most common symptoms of the US resolution outside the US." The countries identified as having markets most likely to be influenced by events in the United States were Brazil, Japan, South Korea, Australia, Chile, South Africa, Canada, and Venezuela, hence industry's interest in litigation developments in Argentina.

Tobacco companies, such as British American Tobacco, closely monitor potential tobacco litigation in certain countries and employ different strategies to prevent litigation before it could start. Once litigation commences, British American Tobacco strategies have included: "(a) share best practices between end-markets; (b) transfer know how from US lawyers to local lawyers; (c) increase value added activities and develop models; and (d) to have ... [local] counsels manage a case without any [British American Tobacco International counsel] involvement." ${ }^{55}$ A recently published article discusses in detail the tobacco industry's analysis of litigation in Argentina as a model for the tobacco industry's concern about tobacco litigation spreading throughout the world. ${ }^{55}$

Some single plaintiff tort cases brought in other countries are yielding similar results to the First and Second Wave cases in the United States. Of 334 tobacco-related cases filed in Brazil, 154 verdicts were issued and only 5 verdicts found for the plaintiff. ${ }^{55}$ Analyzing Argentinean pro-defendant cases, the article found that personal injury cases primarily failed because causation was not established between smoking and the injuries which formed the basis of the suits. Plaintiffs' attorneys did not present scientific evidence or expert witness testimony and often relied on popular media content, such as newspaper articles, to prove their case. Judges also found the "freedom of choice" and "assumption of risk" defenses compelling. "In the 
collective unconscious, there still remains an intense linkage between the notions of smoking and free will. Once again, the social acceptability of smoking in Argentinean society is a barrier to any possible change in tobacco control policies." 55 The tobacco industry also discouraged health care reimbursement cases by emphasizing that in Argentina the losing party must pay the winning party's legal expenses. Therefore Argentinean provinces balked at the risk involved in instituting a suit against the tobacco companies.

The Turkish court system recently heard its first tobacco case in the fall of 2000. ${ }^{56}$ Plaintiff, Yurdagül Tufan, began smoking as a teenager and was the sole provider for her family. After seeing how worried the woman was about the welfare of her family, her doctor decided that suing the Turkish tobacco monopoly, Tekel, would help educate both the patient and the public in Turkey about the tobacco industry's accountability. The doctor found almost no support among his fellow doctors, and during the suit's four-and-a-half year course not a single organization stepped forward in support. Similar to the first and second waves in the United States, the case failed because the judge found insufficient evidence that smoking caused the cancer. The judge also found that the plaintiff freely chose to smoke and therefore assumed risk since she chose to smoke a legal product with clear warning labels. Plaintiff appealed the decision, but in a now familiar story, the plaintiff's side dropped the case due to lack of funds. ${ }^{56}$

Although the case failed in court, it started "an utterly new phenomenon in Turkey" as the nation followed in all media "the disease process, the trial day, the death of the patient and the amount of compensation claimed...". ${ }^{56}$ The defendant, Tekel, also voluntarily changed some of its practices, and the publicity from the case may have helped disrupt its privatization plans.

In a notable decision in a Japanese case involving six former smokers who smoked from 30 to 35 years, the judge rejected the claim. In a 2003 decision, the Tokyo District Court agreed that smoking is injurious to health but did not recognize a causal link between it and the plaintiffs' illnesses. The judge further opined that it cannot be said that manufacturing and selling tobacco is illegal. ${ }^{57}$

Smuggling

It has been estimated that one-third of all internationally exported cigarettes are smuggled and sold on the black market. ${ }^{58}$ Governments lose an estimated total of $\$ 25$ to $\$ 30$ billion dollars in revenue a year from lost taxes..$^{53}$ Because black market cigarettes are not taxed, they are cheaper. The reduced cost encourages consumer use of cigarettes and increases health problems in each country. Government probes and industry documents revealed the tobacco industry's deep involvement in smuggling cigarettes. Certain cigarette companies knowingly sold cigarettes to distributors who would smuggle the product to various countries. In response, in 2000 and 2001, European, Canadian and Latin American governments filed suits against the cigarette industry in the United States..$^{58}$ The charges ranged from negligence to RICO violations. The countries sought lost tax revenues, enforcement costs, and disgorgement of ill-gotten gains. ${ }^{59}$ These smuggling suits were dismissed, because the Revenue Rule bars foreign governments from instituting tax recovery suits in the United States.

The lawsuits in the United States generated more media attention about the reprehensible conduct of the cigarette industry. On April 19, 2002, the television news show "NOW" aired a segment about a six-month investigation into the tobacco industry's involvement with smuggling. ${ }^{60}$ The report conducted extensive interviews across the world with cigarette smugglers, attorneys, trade ministers, and congressmen. As support, the report used incriminating tobacco industry documents that had been released due to prior lawsuits in the United States. For instance, internal documents discussing marketing strategy referred to the illegal cigarettes as "'transit" and "'duty not paid.'"60 The television program showed a secret internal memo that estimated British American Tobacco's cigarettes composed 45 percent of the "transit" market.

The report methodically detailed the tobacco industry's incentives and actions regarding black market cigarettes. Cigarette companies use smuggled cigarettes to establish themselves in countries where they are barred from or restricted in selling their brands. The cheaper price of the smuggled cigarettes allows those brands to compete with local brands and thus expand the company's world market.

The report demonstrated the power of litigation to promote change on the international level. It began with the following message: "While our report begins with revelations about cigarette smuggling, the heart of the matter is the new global economy, and the ability of the legal system to hold US corporations accountable for accusations of wrongdoing overseas. ${ }^{\prime 60}$ Colombia's former Minister of Foreign Trade spoke out in the report. "That it was not something that happened behind their backs, like they claimed[,]" Ronderos said..$^{60} \mathrm{He}$ told about his repeated efforts to get cigarette companies to stop smuggling cigarettes into his country. Columbia turned to litigation in the United States when 
these efforts did not work. Because "the suits stirred up so much media attention, the cigarette companies were forced into an agreement with the Colombian government. Without admitting any wrongdoing, they promised to help stop the smuggling." ${ }^{60}$ The report aired after the smuggling lawsuits were dismissed in the lower courts but while they were still on appeal. It remains a useful source of information to the public today, because the transcript and detailed, supplemental reports are provided on the show's website. ${ }^{60}$

Negative media attention grew further as the European smuggling case wound its way through appeal process, and the undeterred governments had other avenues to seek recovery beyond those particular suits. In this climate, PMI entered into negotiations with the European Union. In July 2004, PMI entered into a "nonsettlement" settlement agreement with the European Community and certain of its Member States. The agreement is entitled the "Anti-Contraband and Anti-counterfeit Agreement and General Release" (Agreement) (available on the European Anti-Fraud Office's website). ${ }^{61} \mathrm{PMI}$ agreed to pay approximately $\$ 1.25$ billion dollars over twelve years. PMI also agreed to alter its supply tracking procedures, to aid in anti-contraband and anti-counterfeit efforts, and to face substantial penalties for future violations. Altria warrants at the end of the Agreement that it and all of its subsidiaries shall abide by the Agreement if they conduct business in the named or Member States; Altria also warrants that it and its subsidiaries shall not "avoid or limit the obligations" of PMI created by the Agreement. ${ }^{61}$ This Agreement between a major cigarette company and a major transnational governmental entity is an important step in stopping international cigarette smuggling.

\section{Environmental tobacco smoke}

Lawsuits involving ETS have been successful in other countries such as Sweden, Britain, and Australia. Like the cases in the United States, the courts and juries find the "victimless" plaintiffs more compelling. Individual plaintiffs have won suits against their employers who did not adequately protect their workers from ETS. Prior history of smoking has not disqualified claimants, as long as the secondhand smoke exposure was a substantial contributing cause of their illness or disability.

In Britain, an employee who worked as a croupier for 14 years sued the casino after he developed asthma. The casino settled with the croupier for $£ 50000$. After the settlement, the croupier continued to advocate in the media for a public ban on smoking in Britain. ${ }^{62}$

In 2001, an Australian jury awarded monetary compensation to a bartender after finding that her employer negligently caused or materially contributed to her throat cancer. A 2002 medical journal article attempted to analyze how the four-person jury found causation based on the evidence produced in the ETS case; the scientific evidence linking ETS with cancer included expert witnesses flown in from the United States, while the evidence used to establish that the plaintiff was sufficiently exposed to ETS to cause the cancer was indirect. ${ }^{63}$ The Australian decision caused a nationwide movement to ban smoking in casinos, restaurants and bars. ${ }^{64}$

Non-governmental organizations (NGOs) are advocacy groups not affiliated with a government. NGOs often work to effect changes on a local level while forming an international network with other NGOs to pool information, resources, and strategies. Some NGOs file, where allowed, "public interest" lawsuits to compel government action to enforce antismoking laws. Some of these suits effected meaningful changes in their countries, especially regarding ETS.

Deora v. Union of India was an NGO-sponsored public interest case that sought to protect the community from ETS. In a 2002 decision, the Supreme Court of India banned smoking in public spaces because of the fundamental right to health of non-smokers until legislation could be passed doing the same. The Court directed the Union of India and other governmental entities to take measures to enforce the ban. The Court noted that the Attorney General for India had pledged to the Court "that Union of India shall take necessary effective steps to give wide publicity to this order by electronic as well as print media to make the general public aware of this order of prohibition of smoking." ${ }^{\prime 65}$ Justice S.B. Sinha, Chief Justice of the Delhi High Court, gave a speech entitled "Environmental Justice in India." ${ }^{\prime \prime 6}$ The central theme was achieving in India a balance among developing the economy, promoting a clean environment, and respecting human rights. He cited the Deora decision in which the high court "stated that nonsmokers cannot be compelled to become helpless victims of pollution caused by cigarette smoke." ${ }^{\prime 66}$

The Supreme Court of India's decision bore strong similarities to an earlier case decided in 1999 in the southwestern Indian state of Kerala. In Ramakrishnan v. State of Kerala, the court determined that ETS was a criminal nuisance and found that exposure to ETS violated a person's fundamental right to life ${ }^{67}$ Noting that the court could not create new legislation, it did exercise its judicial power to compel the executive branch to adopt anti-nuisance orders regarding ETS.

An NGO in Uganda filed a public interest lawsuit asking the high court to declare that ETS in public places violated non-smokers' right to health. "After many 
industry-sponsored interruptions in the case," the court agreed with the NGO and gave the Environmental Management Authority one year to develop procedures to control public smoking. ${ }^{68}$

\section{Other cases}

Class action cases outside the United States currently include two class action cases in Israel about light and ultralight cigarettes ${ }^{69,70}$ and a class action in Brazil under its Consumer Defense Code for deceitful advertising. ${ }^{71}$

\section{Conclusions}

There is now a 50-year experience in the United States of litigation against the tobacco industry. As the base of evidence on health effects has evolved and new legal strategies have emerged, successive waves of litigation have occurred. The many failures of the first and second waves were followed by some notable successes in the third. Litigation by the flight attendants and the states led to substantial settlements and some beneficial consequences for tobacco control. One of the most significant consequences of the state litigation was the access to the industry's documents gained through the Minnesota settlement. These documents further empowered the tobacco control movement and strengthened the basis for legal action. The continuing litigation in the United States remains a threat to the industry, in spite of the mixed outcomes of recent cases.

Experience in other countries is only now emerging. The basis for the suits is wide and to date, a few have been successful. The FCTC provides a broad rationale for litigation, which is likely to be a needed strategy to combat smuggling or other illegal activities. Precedents are still limited. We encourage all nations that are considering litigation to carefully review their existing legal foundations and to consult with international resources, such as the Tobacco Products Liability Project at Northeastern University School of Law in Boston. ${ }^{72}$

\section{Acknowledgements}

This work has been supported in part by the National Institutes of Health (NIH) grant R01 CA 87571 (Miura and Daynard); the Project on Scientific Knowledge and Public Policy (Daynanrd) and by the Fogarty International Center Advisory Council/NIH grant R01HL 073699 (Samet). Drs. Daynard and Samet are both Dr. William Cahan Distinguised Professors of the Flight Attendant Medical Research Institute.

\section{References}

I. Tobacco Documents Online. 2006.

2. Legacy Tobacco Documents Library. University of California San Francisco. 2002.

3. US Department of Health Education and Welfare (DHEW). Smoking and health. Report of the Advisory Committee to the Surgeon General. DHEW Publication No. [PHS] II 03. Washington, DC: U.S. Government Printing Office, 1964.

4. US Department of Health and Human Services (USDHHS). The health effects of active smoking:A report of the Surgeon General. Washington, DC, U.S. Government Printing Office: 2004.

5. US Department of Health and Human Services (USDHHS). The health consequences of smoking-chronic obstructive lung disease. A report of the Surgeon General.Washington, DC: U.S. Government Printing Office, 1984.

6. US Department of Health and Human Services (USDHHS). The health consequences of involuntary smoking: A report of the Surgeon General. DHHS Publication No. (CDC) 87-8398. Washington, DC, U.S. Government Printing Office: 1986.

7. US Environmental Protection Agency (EPA). Respiratory health effects of passive smoking: Lung cancer and other disorders. EPA/600/006F. Washington, DC, U.S. Government Printing Office: 1992.

8. California Environmental Protection Agency (Cal EPA), Office of Environmental Health Hazard Assessment. Health Effects of Exposure to Environmental Tobacco Smoke. California: California Environmental Protection Agency, 1997.

9. Scientific Committee on Tobacco and Health, HSMO. Report of the Scientific Committee on Tobacco and Health. 0I I322124x. 2-5-1998.

The Stationary Office.

10. World Health Organization. International Consultation on Environmental Tobacco Smoke (ETS) and Child Health. Consultation Report. Geneva:World Health Organization, 1999.

I I.International Agency for Research on Cancer (IARC). Tobacco smoke and involuntary smoking. IARC monograph 83. [83]. Lyon, France: International Agency for Research on Cancer, 2004.

12. California Environmental Protection Agency (Cal EPA), Air

Resources Board. Proposed identification of environmental tobacco smoke as a toxic air contaminant. Sacramento, California: Environmental Protection Agency: 2005

13. Stratton K, Shetty P,Wallace R, Bondurant S, eds. Clearing the smoke: assessing the science base for tobacco harm reduction. Washington,DC: National Academy Press, 2001.

14. US Department of Health and Human Services (USDHHS), National Cancer Institute. Risks associated with smoking cigarettes with low machine-measured yields of tar and nicotine. Bethesda, MD: National Institutes of Health, 200I.

15. Zeger SL, Wyant T, Miller LS, Samet JM. Statistical testimony on damages in Minnesota v. Tobacco Industry. In: Gastwirth J, ed. Statistical science in the courtroom. New York: Springer-Verlag, 2000.

16. Rubin DB. Statistical issues in the estimation of the causal effects of smoking due to the conduct of the tobacco industry. In: Gastwirth J, ed. Statistical Science in the Courtroom. New York: Springer-Verlag, 2000: 32I-35I.

17. Samet JM. Dear author-advice from a retiring editor. Am J Epidemiol 1999; 150(5):433-436.

18. Norr R. Cancer by the carton. Reader's Digest 1952. [December]:7-8. 19. Cigarette case. Time 1954;63(17).

20. Kelder JrGE, Daynard RA. The role of litigation in the effective control of the sale and use of tobacco. Stanford Law and Policy Review 1997; 8(63):98. 
21. Hilts PJ. Smokescreen. The truth behind the tobacco industry coverup. Boston:Addison-Wesley, 1996.

22. Kluger R.Ashes to ashes:America's hundred-year cigarette war, the public health, and the unabashed triumph of Philip Morris. New York: Alfred A. Knopf, 1996.

23. Rabin RL.A sociolegal history of the tobacco tort litigation. Stanford Law Review 1992; 44:867.

24. Boeken v. Philip Morris. Tobacco Control Resource Center . 2006.

25. Cipollone v. Liggett Group. 505 U.S. 504, 53I-32. 1992.

26. Daynard RA. Judicial action for tobacco control. In: Roemer R, ed. Legislative action to combat the world tobacco epidemic. Geneva: World Health Organization, 1993: 140.

27. Daynard RA, Bates C, Francey N. Tobacco litigation worldwide. $\mathrm{Br}$ Med J 2000; 320(7227): I I I-I I3.

28.Backgrounder for Boeken v. Philip Morris veredict. Tobacco Control Resource Center 6-I-200I.

29. Backgrounder for Boeken v. Philip Morris punitive damages. Tobacco Control Resource Center 8-9-200I.

30. Levin M.Widow's legal battle with Philip Morris ends. Los Angeles Times 2006 Mar 21.

31. Backgrounder for Williams v. Philip Morris Oregon Supreme Court Decision. (February 2, 2006). Tobacco Control Resource Center 2-6-2006.

32. Guardino SD, Daynard RA. Punishing tobacco industry misconduct: The case for exceeding a single digit ratio between punitive and compensatory damages. University of Pittsburgh Law Review 2005; 67(I). 33. Levin M. Tobacco giant, in a shift, pays a victim. Los Angeles Times 2003 Oct 2

34. Tobacco litigation. Smokin'. The Economist 2005;374(84|3):6I 35. Settlement Agreement. Broin v. Philip Moriss Inc., Case Number 91 . 49738 CA (22). 10-9-1997.

36. Marie Lee v Dep't of Public Welfare et al, No. I5385, I.2 TPLR 2.82. 5-3I-1983.

37. Levin M. Philip Morris wins reversal of verdict. Los Angeles Times 2005 Dec 16.

38. Daynard RA, Parmet W, Kelder G, Davidson P. Implications for tobacco control of the multistate tobacco settlement. Am J Public Health 200I; 9 I(I2): I967-I97I.

39. National Association of Attorneys General. Tobacco public page. National Association of Attorneys General . 2006.

40. Mackay J, Eriksen M. The tobacco atlas. Geneva:World Health Organization, 2002: I- 128.

4I. Racketeer Influenced and Corrupt Organizations Act. I8 U.S.C. 1961. 10-15-1970.

42. Racketeer Influenced and Corrupt Organizations Act. I8 U.S.C.

1962. 10-15-1970.

43. Complaint for Damages and Injunctive and Declaratory Relief. 922-1999.

44. Postrial Brief of the United States of America. United States of America (et al.) v. Philip Morris USA Inc. (et al.); civ. no 99-CV-02496. 8 24-2005.

45. US Department of Justice. Litigation against tobacco companies. US Department of Justice . 10-4-2005.

46. World Health Organization. Framework Convention on Tobacco Control (FCTC). Geneva:World Health Organization, 2003.
47. Meier BM. Breathing life into the framework convention on tobacco control:Smoking cessation and the right to health. Yale Journal of Health Policy, Law \& Ethics 2005; 5(I):I37-192.

48. Crow ME. The human rights responsibilities of multinational tobacco companies. Tob Control 2005; 14 Suppl 2:iil 4-ii 8.

49. World Health Organization. Updated status of the WHO Framework Convention on Tobacco Control. Geneva:World Health Organization, 2006.

50. World Health Organization, Tobacco Free Initiative. The first session of the Conference of the Parties to the WHO Framework Convention on Tobacco Control. Geneva:World Health Organization, 2006. 51. Altrai Group I.Altria 2005 annual report. 2005.

52. The Role of Tobacco in Public Health and Smoking Prevention. Lecture abstract in the course of the Eastern Mediterranean Region (WHO) "Making Smoking History," by the Cypress International Institute for the Environment and Public Health.: Harvard School of Public Health, 2006

53. World Health Organization, Tobacco Free Initiative. Tobacco and poverty: a vicious circle. Geneva:World Health Organization, 2004. 54. Daynard RA. Why tobacco litigation? Tob Control 2003; I2(I): I-2. 55. Flores ML, Barnoya J, Mejia R,Alderete E, Perez-Stable EJ. Litigation in Argentina: challenging the tobacco industry. Tob Control 2006; 15(2):90-96. 56. Karlikaya C. Turkey: first tobacco litigation. Tob Control 2006; I5(2):78. 57. Kyodo News Service. Top court dismisses appeal for damages by cancer-ridden ex-smokers. Tobacco Documents Online . 1-26-2006. 58. Collin J. Controlling the global tobacco epidemic: towards a transnational response. Insights Health 200I;(I).

59. Marsden W. Tobacco companies linked to criminal organizations in lucrative cigarette smuggling. Center for Public Integrity . 3-I-200I 60. Tobacco Traffic. Transcript. "Now" with Bill Moyers (PBS). Public Broadcasting System 4-19-2002.

61. Anti-Contraband and Anti-counterfeit Agreement and General Release. The European Commission 7-9-2004.

62. Roberts M. Passive smoking cost me dearly. BBC News, 2004, Nov 14. 63. Stewart BW, Semmler PC. Sharp v Port Kembla RSL Club: establishing causation of laryngeal cancer by environmental tobacco smoke. Med J Aust 2002; 176(3): I 13-116.

64. Quit Victoria. Summary of Australian and State And Territory legislation on smoking in public places. Quit Victoria, 2005.

65. Murli S. Deora v. Union of India (WP 316/1999). II-2-200I.

66. Sinha SB. Environmental justice in India. The M.C. Bhandari Memorial Lecture 2002.

67. Ramakrishnan v State of Kerala [1999] ICHRL II2.7-12-1999.

68. Oluwafemi A. Regional summary for the African region. In: Shafey O, Dolwick S, Guindon GE, ed. Tobacco control country profiles. Atlanta, GA:American Cancer Society, 2003: 27-3I.

69. El-Roy et al. v. Philip Morris Incorporated et al. District Court of TelAviv/Jaffa, Israel (class cert pending). I- I8-2004.

70. Navon et al. v. Philip Morris Products USA et al. District Court of Tel-Aviv/Jaffa, Israel. I2-5-2004.

7I. The Smoker Health Defense Association (ADESF) v. Souza Cruz S.A. and Philip Morris Marketing S.A. Nineteenth Lower Civil Court of the Central Courts of the Judiciary District of San Paulo, Brazil. 7-25-1995. 72. Tobacco Control Resource Center. Northeastern University. 2006. 